\title{
Host range testing of the nearctic beneficial parasitoid Neodryinus typhlocybae
}

\section{Gudrun Strauss}

Published online: 24 July 2008

(C) International Organization for Biological Control (IOBC) 2008

\section{Erratum to: BioControl}

DOI 10.1007/s10526-008-9176-7

The term 'koinobiont' used in the original publication (page 2, left column, 11th line from bottom) was incorrect. The correct term is 'idiobiont'. 